UDC 517.958:531.32

Doi: $10.31772 / 2587-6066-2020-21-1-8-14$

For citation: Ivanov V. A., Erkaev N. V. Semi-analytical method for calculating elastic-hydrodynamic contact. Siberian Journal of Science and Technology. 2020, Vol. 21, No. 1, P. 8-14. Doi: 10.31772/2587-6066-2020-21-1-8-14

Для цитирования: Иванов В. А., Еркаев Н. В. Полуаналитический метод расчета упругогидродинамического контакта // Сибирский журнал науки и технологий. 2020. Т. 21, № 1. C. 8-14. Doi: $10.31772 / 2587-6066-2020-21-1-8-14$

\title{
SEMI-ANALYTICAL METHOD FOR CALCULATING ELASTIC-HYDRODYNAMIC CONTACT
}

\author{
V. A. Ivanov ${ }^{1,3^{*}}$, N. V. Erkaev ${ }^{2,3}$ \\ ${ }^{1}$ Institute of Computational Technologies SB RAS \\ 6, Akademika Lavrentyeva St., Novosibirsk, 630090, Russian Federation \\ ${ }^{2}$ Institute of Computational Modeling SB RAS \\ 50/44, Akademgorodok, Krasnoyarsk, 660036, Russian Federation \\ ${ }^{3}$ Siberian Federal University, Polytechnic Institute \\ 26, Akademika Kirenskogo St., Krasnoyarsk, 660074, Russian Federation \\ *E-mail: VinTextrim@yandex.ru
}

\begin{abstract}
A semi-analytical method for calculating elastic-hydrodynamic contact based on the partial use of Computer Aided Design / Computer Aided Engineering (CAD / CAE) packages and solutions of the integral equation of functional relationship between pressure and deformation have been described. The pressure in the lubricating layer is described by solving the modernized Reynolds equation taking into account the factors such as elastic deformation of surfaces in the contact zone, cavitation effect in the low-pressure region, and variable viscosity of the lubricant layer, which depends on thermodynamic parameters. Based on the stationary solution, a tensor damping coefficient has been obtained, with the help of which calculations of transient non-stationary modes that occur in cases of a sharp change in the external load have been further performed. A comparison of the results of modeling a plain bearing obtained by using the proposed semi-analytical method has been made and the full calculation performed using CAD / CAE programs such as ANSYS and COMSOL Multiphysics. The comparison showed good convergence of all numerical methods. At the same time, the "hybrid" method showed a number of advantages over direct calculations in CAD / CAE packages, such as: faster calculation speed, low requirements for computing resources and accounting for the cavitation effect. The described semi-analytical method allows to create digital twins of bearing units, centrifugal pumps and hydraulic supports used in satellite cooling systems and in rotary mechanisms of ground-based satellite dishes.
\end{abstract}

Keyword: hybrid modeling, digital twins, elastic-hydrodynamic contact.

\section{ПОЛУАНАЛИТИЧЕСКИЙ МЕТОД РАСЧЕТА УПРУГО-ГИДРОДИНАМИЧЕСКОГО КОНТАКТА}

\author{
В. А. Иванов ${ }^{1,3^{*}}$, Н. В. Еркаев ${ }^{2,3}$ \\ ${ }^{1}$ Институт вычислительных технологий СО РАН \\ Российская Федерация, 630090, г. Новосибирск, просп. Академика Лаврентьева, 6 \\ ${ }^{2}$ Институт вычислительного моделирования СО РАН \\ Российская Федерация, г. Красноярск, Академгородок, 55, стр. 44 \\ ${ }^{3}$ Сибирский федеральный университет, Политехнический институт \\ Российская Федерация, 660074, г. Красноярск, ул. Академика Киренского, 26 \\ *E-mail: VinTextrim@yandex.ru
}

\begin{abstract}
Описан полуаналитический метод расчета упруго-гидродинамического контакта, основанный на частичном использовании Cотриter Aided Design / Coтputer Aided Engineering (CAD/CAE) пакетов и решения интегрального уравнения функииональной связи между давлением и деформацией. Давление в смазочном слое описьвается решением модернизированного уравнения Рейнольдса с учетом таких факторов, как упругая деформация поверхностей в зоне контакта, эффект кавитаџии в области низкого давления, переменная вязкость смазочного слоя, зависящая от термодинамических параметров. На основе стационарного решения получен тензорный коэффициент демпфирования, с помощью которого далее выполняются расчеты переходных нестационарных режимов, возникающих в случаях резкого изменения внешней нагрузки. Проведено сравнение результатов моделирования подщипника скольжения, полученных с помощью предложенного полуаналитического метода и полного расчета, выполненного с помощью CAD/CAE программ, таких как ANSYS и COMSOL
\end{abstract}


Multiphysics. Сравнение показало хорошую сходимость всех численных методов. При этом «гибридный» метод показал ряд преимуществ по сравнению с прямыми расчетами в САD/САЕ пакетах, таких как более быстрая скорость расчета, невысокие требования к вычислительным ресурсам и учет кавитационного эффекта. Описанный полуаналитический метод позволяет создавать ичифровые двойники подиипниковых узлов, иентробежных насосов и гидроопор, использующихся в спутниковых системах охлаждения и поворотных механизмах наземных спутниковых антенн.

\section{Ключевые слова: гибридное моделирование, ичифровые двойники, упруго-гидродинамический контакт.}

Introduction. In today's world, practically any engineer designing a moving mechanical system faces contact tasks in friction units. Modern trends in the design of aircraft friction units set severe constraints: maximum weight reduction with full durability retention. One of the most difficult things is contact problems of elastichydrodynamic interaction between two bodies, as it requires simultaneous consideration of many factors, such as elastic surfaces deformation, pressure and temperature dependent viscosity of the liquid layer and lubricant foaming in low pressure zones. The most challenging problem is deformation of the elastic surface, as under high loads it significantly affects the value of the geometric clearance in the liquid layer. There is a number of approximate analytical solutions to such problems [1-6], obtained within the framework of simplifying assumptions, which do not allow to solve the contact problem with high accuracy. Various multidisciplinary CAD/CAE software applications are now widely available (CAD Computer Aided Design, CAE - Computer Aided Engineering) Complexes (ANSYS, SolidWorks, COMSOL Multiphysics, etc.). However, the use of such complexes for calculating non-stationary elastic-hydrodynamic tasks faces considerable difficulties due to the presence of very thin layers, huge pressure drops and rigidity of nonstationary tasks, which require very short steps in time and space. All these lead to sufficient computational and time costs. In this case, it makes sense to combine analytical methods with limited numerical modeling to solve specific engineering problems. Such an approach of "hybrid" modeling allows to build a complete digital dynamic model of a projected or real unit, and to study its operability when various external factors change. This is particularly true for hard to access or completely unserviceable units, such as centrifugal pumps used for spacecraft cooling systems [7]. As an example, we will use the plain bearing schematically shown in fig. 1 .

Here, $\omega$ is the angular speed of shaft rotation, $\varphi$ is the azimuthal angle counted clockwise from the maximum clearance point, $\eta$ and $R_{0}$ are eccentricity and radius of the cylindrical shaft, $R_{1}$ is the inner radius of the liner, $R_{2}$ and $R_{3}$ are the inner and outer radii of the cylindrical case, $L$ is the bearing length. In calculations we use zero boundary conditions for deformations at the specified external boundary of the bearing case. A thin layer of liquid lubricant, called a lubricating layer, is disposed between the shaft and the liner. We also set zero boundary conditions for pressure at the bearing ends.

Separation of elastic and hydrodynamic tasks. One promising way of simplifying a general elastichydrodynamic problem is to divide it into sequentially solved simpler tasks: a hydrodynamic task related to pressure determination in liquid layer, and a contact task based on the determination of elastic deformation.

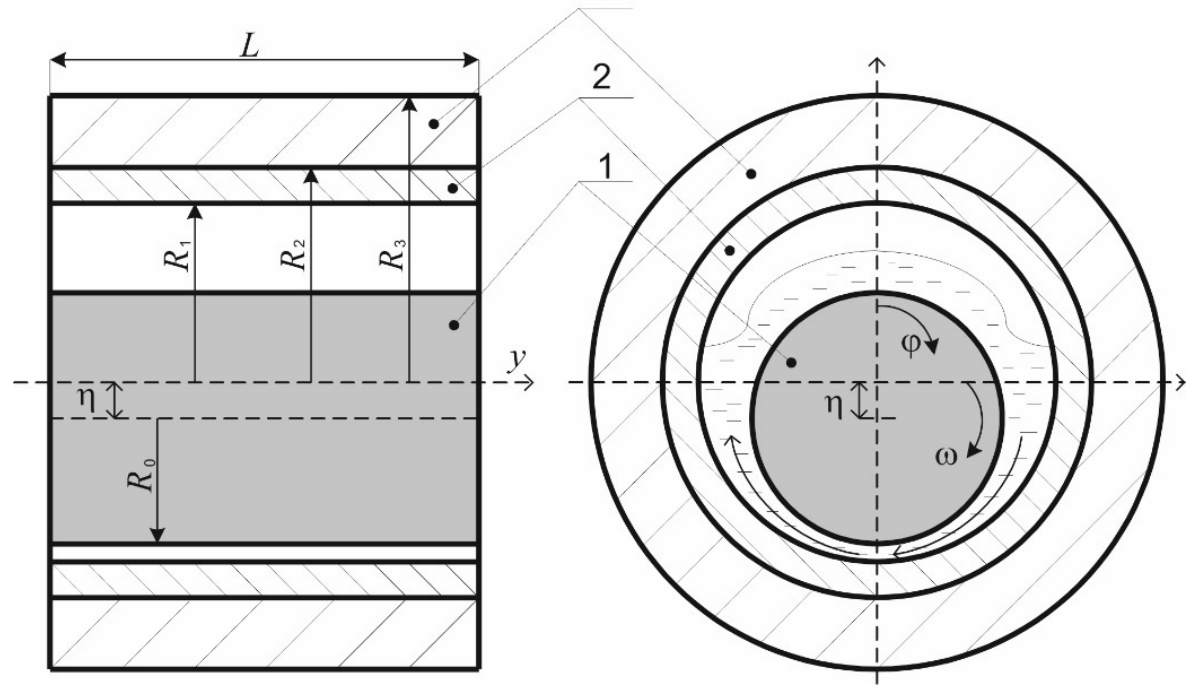

Fig. 1. Geometric diagram of a plain bearing: 1 - shaft; 2 - bronze liner; 3 - case

Рис. 1. Геометрическая схема подшипника скольжения: 1 - вал; 2 - бронзовый вкладыш; 3 - корпус 
The relationship between elastic strain and pressure can generally be represented as follows:

$$
\delta(x)=\int_{\Omega} P\left(x^{\prime}\right) K\left(x-x^{\prime}\right) d \Omega,
$$

where $\delta$ and $P$ are surface deflection and corresponding pressure, $\Omega$ is a contact pad. Function $K\left(x-x^{\prime}\right)$, which is a kernel of linear functional will be called flexibility function.

Flexibility function of $K\left(x-x^{\prime}\right)$ is a key element in the method of elastic and hydrodynamic task solutions. It is important to note that this function can be defined independently of the hydrodynamic problem solution. Thus, by setting some pressure distribution at the boundary of the bodies, it is possible to define appropriate deflection function $\delta$ as a result of the solution to the elastic problem for contact bodies.

Further, under the known functions $\delta$ and $P$, equation (1) can be considered as an integral equation with reference to function $K\left(x-x^{\prime}\right)$ which can be solved by decomposition on some orthogonal basis:

$$
K\left(x-x^{\prime}\right)=\sum_{k=0}^{n}\left[M_{k} \Phi_{k}\left(x-x^{\prime}\right)+N_{k} \Psi_{k}\left(x-x^{\prime}\right)\right],
$$

where $M_{k}$ and $N_{k}$ are orthogonal decomposition coefficients. In most cases, $\Omega$ zone can be considered rectangular and select trigonometric functions as basic functions for which the following equations are true:

$$
\begin{aligned}
& \Phi_{k}\left(x-x^{\prime}\right)=\Phi_{k}(x) \Psi_{k}\left(x^{\prime}\right)-\Psi_{k}(x) \Phi_{k}\left(x^{\prime}\right), \\
& \Psi_{k}\left(x-x^{\prime}\right)=\Psi_{k}(x) \Psi_{k}\left(x^{\prime}\right)+\Phi_{k}(x) \Phi_{k}\left(x^{\prime}\right) .
\end{aligned}
$$

Adding (3) to (1), the following quotation system is obtained

$$
\begin{aligned}
& \left\|\Phi_{k}\right\|^{2}\left[M_{k}\left(P \cdot \Phi_{k}\right)+N_{k}\left(P \cdot \Psi_{k}\right)\right]=\left(\delta \cdot \Phi_{k}\right), \\
& \left\|\Psi_{k}\right\|^{2}\left[M_{k}\left(P \cdot \Psi_{k}\right)-N_{k}\left(P \cdot \Phi_{k}\right)\right]=\left(\delta \cdot \Psi_{k}\right) .
\end{aligned}
$$

where

$$
\left\|\Phi_{k}\right\|^{2}=\left\|\Psi_{k}\right\|^{2}=\left(\Phi_{k} \cdot \Phi_{k}\right)=\left(\Psi_{k} \cdot \Psi_{k}\right) .
$$

As a result of the system solution (4), the orthogonal decomposition coefficients $M_{k}$ and $N_{k}$, are calculated, thereby flexibility function is determined (2). It is important to note that restoring the flexibility function is an "incorrect task" [8] in which small-scale errors in the input data cause significant deviations in the outcome results. Therefore, to smooth the flexibility function, it is necessary to apply regularization [9].

Calculation of pressure. Pressure distribution $P$ in the lubricating layer is determined from Reynolds equation [10]

$$
\operatorname{div}\left[\frac{h^{3}}{12 \mu} \nabla P\right]=\frac{1}{2} \nabla(\vec{V} h)+\frac{\partial h}{\partial t},
$$

where $h$ - liquid layer thickness, $V$ - sum of body velocities in the contact point

$$
\vec{V}=\vec{V}_{1}+\vec{V}_{2} .
$$

At the same time thickness of the liquid layer $h$ considers both the geometrical clearance between the contacting $h_{g}$ bodies and the deformation of elastic $\delta$ of the surface caused by excessive pressure in the layer

$$
\begin{gathered}
h=1+\eta \cos (\varphi)+\int_{0}^{2 \pi} P\left(\varphi^{\prime}\right) K\left(\varphi-\varphi^{\prime}\right) d \varphi, \quad P>0 ; \\
\vec{V} \nabla h=0, \quad P \leq 0,
\end{gathered}
$$

Where $K\left(\varphi-\varphi^{\prime}\right)$ is a flexibility function independent of the pressure distribution in the layer, but taking into account the geometric and elastic properties of the contacting materials [11].

It should be noted that equation (7) takes into account the cavitation effect (foaming) under negative pressure.

Importantly, viscosity of the lubricant layer $\mu$ strongly depends on the temperature $T$ and pressure $P$. There is a set of empirical models of liquid layer viscosity change $[12 ; 13]$, however the most accurate of which is Petrusevich's formula which approximates dependence of viscosity on temperature and pressure in an exponential view:

$$
\mu(P, T)=\mu_{0} \exp \left(\alpha P-\Omega_{0} T\right),
$$

where $\alpha$ is piezoelectric coefficient characterizing the change in viscosity depending on pressure, $\mu_{0}$ is dynamic viscosity at $P=0, \Omega_{0}$ is a so-called viscosity slope coefficient.

Thermal calculation. Calculation of heat generating power $Q$ for the plain bearing operating in hydrodynamic mode is defined by

$$
Q=\frac{h^{3}}{12 \mu}\left[\left(\frac{\partial P}{\partial y}\right)^{2}+\frac{1}{R_{1}^{2}}\left(\frac{\partial P}{\partial \varphi}\right)^{2}\right]+\frac{\mu}{h} V^{2} .
$$

Let's write down the thermal conductivity equation in cylindrical coordinates:

$$
\frac{1}{r} \frac{\partial}{\partial r}\left(r \frac{\partial T}{\partial r}\right)+\frac{1}{r^{2}} \frac{\partial^{2} T}{\partial \varphi^{2}}=0 .
$$

Solution to equation (10) can be represented as Fourier decomposition:

$$
T=a_{0}+\sum_{k=1}^{\infty}\left[a_{k} \cos (k \varphi)+b_{k} \sin (k \varphi)\right]+T_{0} .
$$

At the inner boundary under $r=R_{1}$ we have a boundary condition for heat flow from the lubricating layer:

$$
Q=-\chi \frac{\partial T}{\partial r},
$$

where $Q$ is the heat generating power in the lubricating layer, defined by formula (9). The heat emission power function is also Fourier decomposed by harmonics:

$$
\begin{gathered}
Q=\Theta_{0}+\sum_{k=1}^{\infty}\left[\Theta_{k} \cos (k \varphi)+\Theta_{k} \sin (k \varphi)\right], \\
\Theta_{k}=\frac{1}{\pi} \int_{0}^{2 \pi} Q(\varphi) \cos (k \varphi) d \varphi
\end{gathered}
$$




$$
\begin{gathered}
\Theta_{k}^{*}=\frac{1}{\pi} \int_{0}^{2 \pi} Q(\varphi) \sin (k \varphi) d \varphi,(k=1,2,3 \ldots) ; \\
\Theta_{0}=\frac{1}{2 \pi} \int_{0}^{2 \pi} Q(\varphi) d \varphi .
\end{gathered}
$$

At the outer boundary we set the ambient temperature $T_{0}$ :

$$
T\left(R_{3}\right)=T_{0} .
$$

Applying Fourier decomposition to formula (12), we obtain the equations

$$
-\chi \frac{\partial a_{k}}{\partial r}=\Theta_{k}, \quad-\chi \frac{\partial b_{k}}{\partial r}=\Theta_{k}^{*} .
$$
tions:

Here, the factors $a_{k}, b_{k}$ satisfy the differential equa-

$$
\begin{gathered}
\frac{1}{r} \frac{\partial}{\partial r}\left(r \frac{\partial a_{k}}{\partial r}\right)-\frac{k^{2}}{r^{2}} a_{k}=0, \\
\frac{1}{r} \frac{\partial}{\partial r}\left(r \frac{\partial b_{k}}{\partial r}\right)-\frac{k^{2}}{r^{2}} b_{k}=0, \\
\frac{1}{r} \frac{\partial}{\partial r}\left(r \frac{\partial a_{0}}{\partial r}\right)=0 .
\end{gathered}
$$

While solving equations (16), we define coefficients $a k$ and $b k$ :

$$
\begin{gathered}
a_{k, j}=\Theta_{k, j} \tilde{a}_{k}, \quad b_{k, j}=\Theta_{k, j}^{*} \tilde{a}_{k} \\
\tilde{a}_{k}=-\frac{R_{3}}{k} \frac{1}{\chi\left[\left(\frac{R_{1}}{R_{3}}\right)^{k-1}+\left(\frac{R_{3}}{R_{1}}\right)^{k+1}\right]}\left[\left(\frac{R_{1}}{R_{3}}\right)^{k}-\left(\frac{R_{3}}{R_{1}}\right)^{k}\right] \\
\tilde{a}_{0}=\frac{R_{1}}{\chi} \ln \frac{R_{3}}{R_{1}} .
\end{gathered}
$$

Non-stationary loading. In case of sharp changes of external load $F$, disturbances in center-of-mass velocity occur, causing non-stationary shifts of liquid layer thickness and pressure distribution in contact zone, which leads to the change in the force reaction of the liquid layer against the external load associated with the pressure by the equation

$$
\vec{W}=\int P \vec{N} d x^{\prime} .
$$

Under minor center-of-mass velocity disturbances, equation (18) can be represented as decomposition

$$
\vec{W}=\vec{W}_{0}\left(\vec{x}_{c}\right)-\vec{\lambda} \dot{\vec{x}}_{c}
$$

Here, the left part of the equation takes into account stationary bearing capacity of $W_{0}$, while the right part velocity disturbance in the center-of-mass, the tensor coefficient $\lambda$ is a layer damping coefficients matrix. These coefficients determine pressure relaxation in the lubricating layer during non-stationary transient processes. The found functions of stationary carrying capacity and damping coefficients allow to write equation of body dynamics in the following form:

$$
M \ddot{x}_{c}+\vec{\lambda}_{\vec{x}}-\vec{W}_{0}\left(\vec{x}_{c}\right)=-F .
$$

The above method allows to find a self-consistent non-stationary solution to the problem of elastichydrodynamic interaction of bodies with any geometric parameters, with respect to their deformation. Based on this method a program has been written (in more detail [14]), which allows to efficiently calculate the selfconsistent pressure distribution in the lubricating layer of the plain bearing. However, by changing clearance equation in the lubricating layer for another type of contact, the program becomes universal.

Comparison of proposed calculation method with CAD/CAE programs. Calculation of plain bearing lubricating layer (fig. 1) applying the above method is compared with the same calculation using ANSYS software complex based on finite element method. The calculation flowchart for both methods is shown in fig. 2 .

Let's consider fig. 2 in more detail. In the first step of the "hybrid" method, we model the elastic deflection of the plain bearing in the ANSYS program (any other calculation program can be used, this is not fundamental) and set the load as an arbitrary distribution of pressure along the surface. As a result of calculation, elastic deflection of the liner is determined, which finishes the complex $\mathrm{CAD} / \mathrm{CAE}$ programs use.

Further, knowing the pressure distribution in the lubricating layer and the corresponding elastic deformations, we restore the flexibility function according to the method described above. Then we shift to iterative calculation of lubricating layer [14], which takes into account variable viscosity of lubricant, cavitation effect, temperature change inside the layer and deformation of elastic surface. It is important to note that this algorithm is easily implemented in almost any software environment and makes calculations quickly and accurately for any load or eccentricity values.

When performing a full calculation in an ANSYS package, it is initially necessary to simulate the lubricating layer in ANSYS Fluid Flow, which at first glance should not cause any problems. However, at values of relative eccentricity of bearing more than 0.8 there are difficulties in modeling as the value of lubricating layer thickness becomes less than permissible $\left(10^{-7} \mathrm{~m}\right)$. With these values, most $\mathrm{CAD} / \mathrm{CAE}$ programs issue a simulation error and build a surface rather than a solid. In addition, $\mathrm{CAD} / \mathrm{CAE}$ packages cannot take the cavitation effect into account, which affects the maximum pressure. Considering these limitations, we model a lubricating layer and determine the pressure generated by it, as well as calculate the heat generating power and temperature in the lubricating layer.

Next step is to simulate the bearing case, performing the same actions as in modeling deformation of the elastic layer in the "hybrid" method. The only difference is that the pressure distribution across the elastic layer is imported from the previously calculated lubricating layer. In order to shift to a non-stationary calculation, it is necessary to perform calculations for at least three different lubricating layers, that is, for three different values of relative eccentricity. The results are imported into ANSYS Twin Builder. Based on the previously obtained data, this package builds a lower-order plain bearing model by numerical approximation of the results, which 
allows to determine in real time how the liner deflection and pressure change in the lubricating layer at a smooth change of load.

Let's compare the results of the solutions (fig. 3) obtained by "hybrid" modeling and modeling in ANSYS and SOMSOL Multiphysics packages [15]. Calculation was carried out for the following parameters: $L=0.125 \mathrm{~m}$, $R_{1}=0.25 \mathrm{~m}, \mu=0.19 \mathrm{~Pa} \cdot \mathrm{c}$, relative eccentricity $\tilde{\eta}=0.5 \eta$, shaft rotation speed of $1000 \mathrm{rpm}$.

From fig. 3, calculations performed in ANSYS (curve 4) and COMSOL Multiphysics (curve 3) show the same results (difference not exceeding $1 \%$ ). Both calculations do not take into account the cavitation effect, which leads to a $15 \%$ reduction in the maximum pressure compared to the "hybrid" method of calculation, taking into account the cavitation effect and excluding occurrence of negative pressure regions (curve 1). The results of the calculation using the "hybrid" method without cavitation are well consistent with the calculations in $\mathrm{CAD} / \mathrm{CAE}$ packages where the difference of maximum pressures in the layer does not exceed $6 \%$.

Comparative analysis of the above described results suggests that the semi-analytical "hybrid" calculation method shows good calculation accuracy provided its cost effectiveness. Herein, it has a number of advantages over numerical calculations in $\mathrm{CAD} / \mathrm{CAE}$ programs. The first and rather significant advantage is the "cost of calculation" CAD/CAE packages that allow a number of calculations described above and have the required functionality have a very high cost, while any package that can perform static calculations (for example, ANSYS Student package) will be suitable for "hybrid" modeling. The second advantage of "hybrid" modeling is low computing resource requirements, while calculations in $\mathrm{CAD} / \mathrm{CAE}$ packages require powerful computers that are also expensive.
A

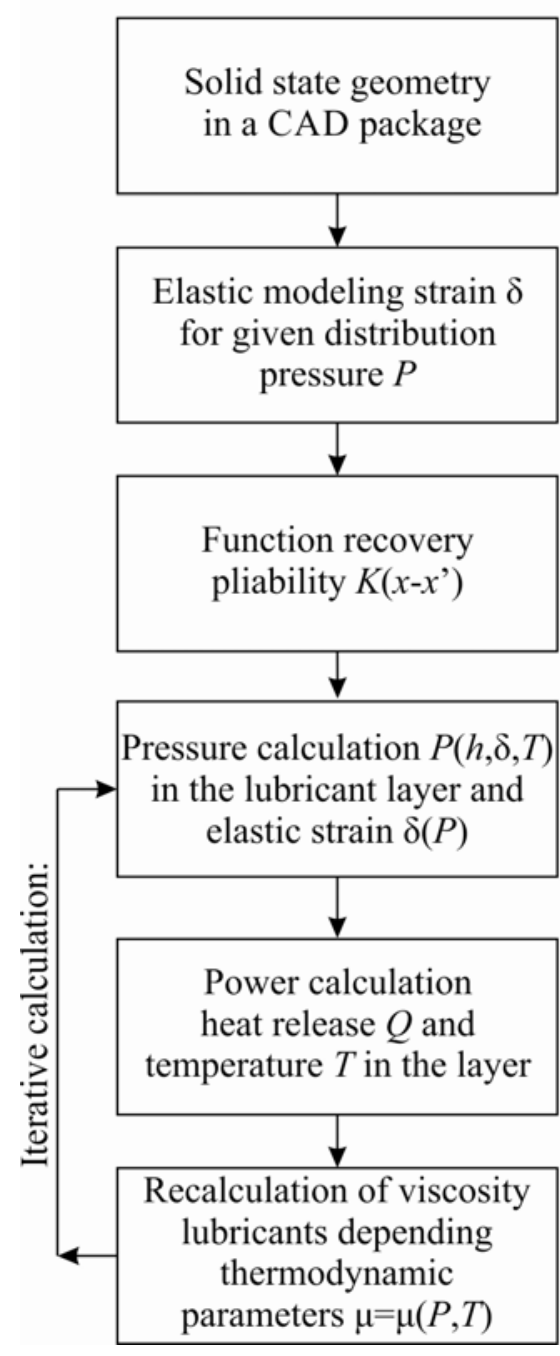

B

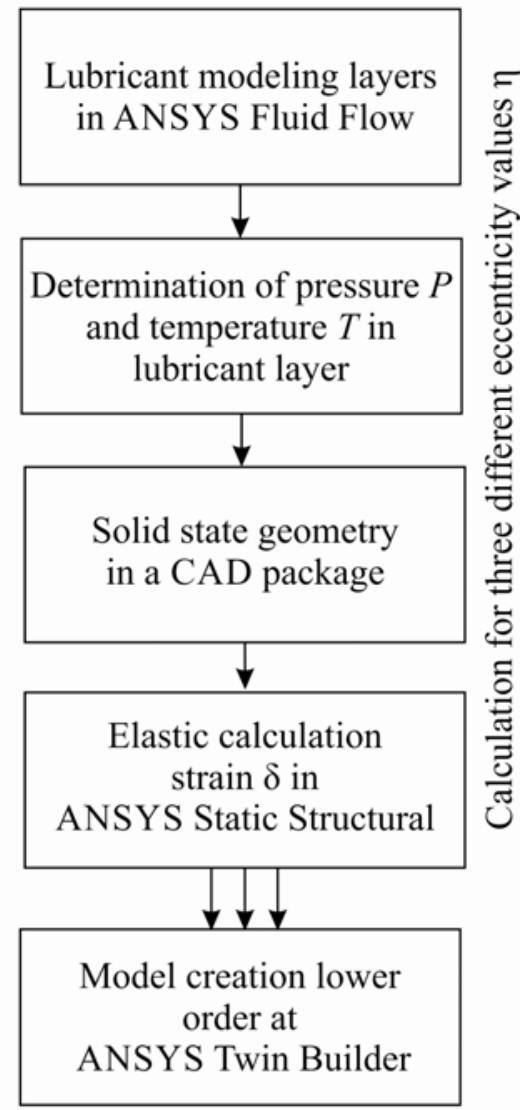

Fig. 2. Flowchart of methods for plain bearing calculation: $A$ - proposed "hybrid method"; $B$ - calculation method using ANSYS

Рис. 2. Блок-схема методов расчета подшипника скольжения: $A$ - предлагаемый «гибридный метод»; $D$ - методика расчета в ANSYS 


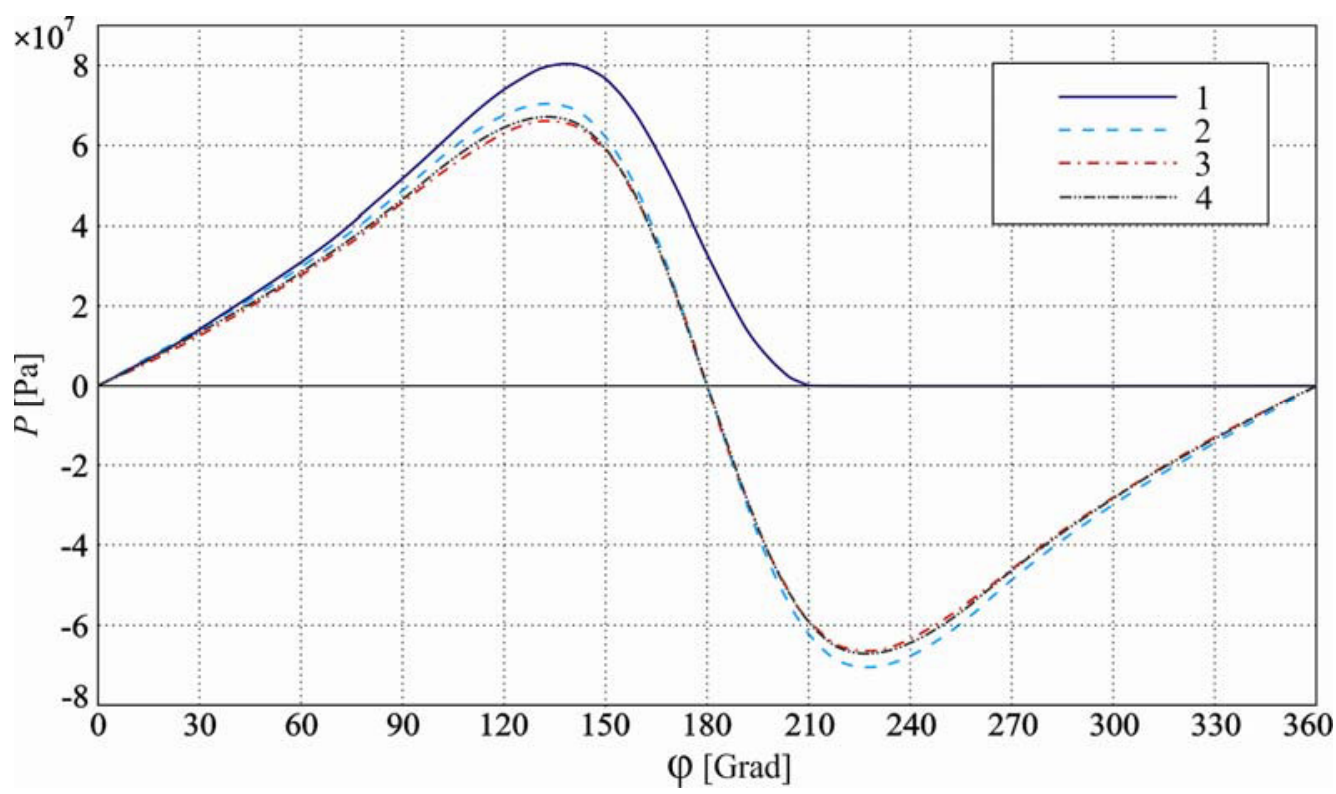

Fig. 3. Pressure in the lubricating layer of the plain bearing:

1 - semi-analytical solution that takes into account the cavitation effect; 2 - semi-analytical solution without taking into account the cavitation effect; 3 - modeling in COMSOL Multiphysics; 4 -modeling in ANSYS

Рис. 3. Давление в смазочном слое подшипника скольжения:

1 - полуаналитическое решение, учитывающее кавитационный эффект; 2 - полуаналитическое решение без учета кавитационного эффекта; 3 - моделирование в COMSOL Multiphysics; 4 - моделирование в ANSYS

The calculated and most important advantage of the "hybrid" simulation is the possibility of non-stationary calculation of the heavily loaded operation of the plain bearing or other type of contact interaction (the calculation technique will differ only by the clearance equation for a particular type of contact).

First, in a "hybrid" simulation, it is possible to set any size of the minimum clearance without restrictions for super-heavy loads. At the same time, modeling in $\mathrm{CAD} / \mathrm{CAE}$ packages has a limit for minimum clearance values.

Second, "hybrid" modeling allows to take into account additional important physical factors that greatly complicate calculation: cavitation effect, which significantly affects pressure peak, variable viscosity of the lubricating layer, dependence on thermodynamic parameters, as well as sharp increase of pressure peak in the layer at sharp load jump. In CAD/CAE packages, this jump is not taken into account and the pressure rise occurs smoothly from the initial value to a new one with reference to the changed load.

Conclusion. The proposed method of "hybrid" simulation allows to calculate non-stationary elastichydrodynamic contact with minimal cost analysis, design and calculation resources taking into account such factors as elastic surface deformation, variable viscosity of lubricating layer and cavitation effect. This calculation method can be used in various engineering or technological departments to pre-evaluate a design unit, to optimize the existing one, as well as to create a digital twin of the friction unit in operation and to determine conditions of its normal performance in particular circumstances.

\section{References}

1. Williams J. A. Engineering tribology. New York, Oxford University Press Inc., 1994, 242 p.

2. Hamrock B. J., Schmid S. R., Jacobson B. O. Fundamentals of fluid film lubrication. New York, Marcel Dekker, Inc., 2004, 703 p.

3. Bair S. High-Pressure Rheology for quantitative elastohydrodynamics. Tribology and Interface Engineering Series. Elsevier, 2007, 54 p.

4. Szeri A. Z. Fluid film lubrication. Cambridge, Cambridge University Press, 2011, 273 p.

5. Lugt P. M., Morales-Espejel G. T. A Review of elasto-hydrodynamic lubrication theory. Tribology Transactions. 2011, Vol. 54, P. 470-496.

6. Galakhov M. A., Usov P. P. Differentsial'nye i integral'nye uravneniya matematicheskoy teorii treniya [Differential and integral equations of the mathematical theory of friction]. Moscow, Nauka Publ., 1990, 280 p.

7. Borovin G. K., Protopopov A. A. [Calculation of the optimal axial clearance of the semi-open impeller of the low-flow centrifugal pump of the spacecraft thermal control system]. Preprinty IPM im. M.V. Keldysha. 2013, No. 86, 16 p. (In Russ.).

8. Tikhonov A. N. Arsenin V. Ya. Metody resheniya nekorrektnykh zadach [Methods for solving incorrect tasks]. Moscow, Nauka Publ., 1979, 288 p.

9. Ivanov V. A., Erkaev N. V. [Nostedy ocillations of the roller contacting with riding surface with lubrication layer]. Vestnik SibGAU. 2017, Vol. 18, No. 1, P. 50-57 (In Russ.).

10. Terentev V. F., Erkaev N. V., Dokshanin S. G. Tribonadejnost podshipnikovix uzlov $v$ prisutstvii modifi- 
cirovanix smazochnix kompozicii [Tribo-durability of bearing units in a presence of modified lubricant compositions]. Novosibirsk, Nauka Publ., 2003, 142 p.

11. Ivanov V. A., Erkaev N. V. [Iterative calculation of trubo-contact between a roller and plate]. Vestnik SibGAU. 2014, No. 4(56), P. 48-54 (In Russ.).

12. Besportochnyy A. I., Galakhov M. A. Matematicheskoe modelirovanie v tribotekhnike. [Mathematical modeling in tribology]. Moscow, MFTI Publ., 1991, $88 \mathrm{p}$.

13. Galin L. A. Kontaktnye zadachi teorii uprugosti $i$ vyazkouprugosti [Contact problems of the theory of elasticity and viscoelasticity]. Moscow, Fizmatlit Publ., 1980, $304 \mathrm{p}$.

14. Ivanov V. A. [Program complex of pressure calculation in lubricated slide bearing layer]. Siberian Journal of Science and Technology. 2018. Vol. 19, No. 3, P. 540-549 (In Russ.).

15. Ravindra M., Sandeep S. Analysis of hydrodynamic plain journal bearing. Excerpt from the Proceedings COMSOL Conference in Bangalore. 2013.

\section{Библиографические ссылки}

1. Williams J. A. Engineering tribology. N.-Y. : Oxford University Press Inc., 1994. 242 p.

2. Hamrock B. J., Schmid S. R., Jacobson B. O. Fundamentals of fluid film lubrication. N.-Y. : Marcel Dekker, Inc., 2004. 703 p.

3. Bair S. High-Pressure Rheology for quantitative elastohydrodynamics // Tribology and Interface Engineering Series. Elsevier, 2007. 54 p.

4. Szeri A. Z. Fluid film lubrication. Cambridge : Cambridge University Press, 2011. 273 p.

5. Lugt P. M., Morales-Espejel G. T. A Review of elasto-hydrodynamic lubrication theory // Tribology Transactions. 2011. Vol. 54. P. 470-496.
6. Галахов М. А., Усов П. П. Дифференциальные и интегральные уравнения математической теории трения. М. : Наука, 1990. 280 с.

7. Боровин Г. К., Протопопов А. А. Расчет оптимального осевого зазора полуоткрытого рабочего колеса центробежного малорасходного насоса системы терморегулирования космического аппарата // Препринты ИПМ им. М. В. Келдыша. 2013. № 86.16 с.

8. Тихонов А. Н., Арсенин В. Я. Методы решения некорректных задач. М. : Наука, 1979. 288 с.

9. Иванов В. А. Еркаев Н. В. Нестационарные колебания ролика, контактирующего с твердой поверхностью, при наличии смазочного слоя // Вестник СибГАУ. 2017. Том 18, № 1. С. 50-57.

10. Терентьев В. Ф., Еркаев Н. В., Докшанин С. Г. Трибонадежность подшипниковых узлов в присутствии модифицированных смазочных композиций. Новосибирск : Наука, 2003. 142 с.

11. Иванов В. А., Еркаев. Н. В. Итерационный расчет трибоконтакта ролика с пластиной // Вестник СибГАУ. 2014. № 4 (56). С. 48-54.

12. Беспорточный А. И., Галахов М. А. Математическое моделирование в триботехнике. М. : МФТИ, $1991.88 \mathrm{c.}$

13. Галин Л. А. Контактные задачи теории упругости и вязкоупругости. М. : Физматлит., 1980. 304 с.

14. Иванов В. А. Программный комплекс расчета давления в смазочном слое подшипника скольжения // Сибирский журнал науки и технологий. 2018. Т. 19, № 3. C. 540-549.

15. Ravindra M., Sandeep S. Analysis of hydrodynamic plain journal bearing // Excerpt from the Proceedings COMSOL Conference in Bangalore. 2013.

(c) Ivanov V. A., Erkaev N. V., 2020

Ivanov Viktor Andreevich - Cand. Sc., researcher, laboratory of digital twins and big data analysis, Institute of Computational Technologies SB RAS; assistant of Applied mechanics department, Siberian Federal University, Polytechnic Institute. E-mail: Vintextrim@yandex.ru.

Erkaev Nikolai Vasilievich - Dr. Sc., professor, principle research scientist, Institute of Computational Modelling SB RAS; Professor of Applied mechanics department, Siberian Federal University, Polytechnic Institute. E-mail: nerkaev@gmail.com.

Иванов Виктор Андреевич - кандидат технических наук, научный сотрудник лаборатории цифровых двойников и анализа больших данных, Институт вычислительных технологий СО РАН; ассистент кафедры прикладной механики, Сибирский федеральный университет, Политехнический институт. Е-таil: Vintextrim@yandex.ru.

Еркаев Николай Васильевич - доктор физико-математических наук, профессор, главный научный сотрудник, Институт вычислительного моделирования СО РАН; профессор кафедры прикладной механики, Сибирский федеральный университет, Политехнический институт. E-mail: nerkaev@gmail.com. 